\begin{tabular}{|l|l|l||}
\hline \multicolumn{2}{|c|}{ PublisherInfo } \\
\hline \hline PublisherName & $:$ & BioMed Central \\
\hline \hline PublisherLocation & $:$ & London \\
\hline \hline PublisherImprintName & $:$ & BioMed Central \\
\hline \hline
\end{tabular}

\title{
Bone anabolic effects of statins
}

\begin{tabular}{|l|l|l||}
\hline \multicolumn{2}{|c||}{ ArticleInfo } \\
\hline \hline ArticleID & $:$ & 213 \\
\hline \hline ArticleDOI & $:$ & $10.1186 /$ ar-2000-66772 \\
\hline \hline ArticleCitationID & $:$ & 66772 \\
\hline \hline ArticleSequenceNumber & $:$ & 170 \\
\hline \hline ArticleCategory & $:$ & Paper Report \\
\hline \hline ArticleFirstPage & $:$ & 1 \\
\hline \hline ArticleLastPage & $:$ & 3 \\
\hline \hline & & RegistrationDate : 2000-1-10 \\
\hline ArticleHistory & $:$ & OnlineDate \\
\hline \hline ArticleCopyright & $:$ & Current Science Ltd2000-1-10 \\
\hline \hline ArticleGrants & $:$ & \\
\hline \hline ArticleContext & $:$ & 130753311 \\
\hline \hline
\end{tabular}


Mike Rogers, ${ }^{\text {Aff1 }}$

Aff1 Aberdeen, UK

\section{Keywords}

BMP-2, bone, osteoblast, osteoclast, osteoporosis, statin

\section{Context}

Excessive osteoclast activity and loss of bone are characteristic features of diseases such as postmenopausal osteoporosis and rheumatoid arthritis. Although bone resorption can be prevented by agents such as bisphosphonates, estrogen or selective estrogen receptor modulators, there are currently no drugs available with bone anabolic properties capable of replacing substantial amounts of bone. To identify agents that may stimulate the production of bone morphogenetic protein (BMP)-2 by osteoblasts (boneforming cells). Since BMP-2 is a powerful stimulator of osteoblast differentiation, such agents could have anabolic effects on bone in vivo.

\section{Significant findings}

Using the reporter assay, BMP-2 expression was stimulated by 1-5 ?molar of the fungal metabolite lovastatin, and the related statins fluvastatin, mevastatin and simvastatin. These compounds also stimulated BMP-2 production by osteoblasts, and increased osteoblast proliferation and bone formation in organ cultures of bone in vitro and when injected over the calvaria of mice. Finally, oral administration of simvastatin increased the volume of trabecular bone and increased the rate of bone formation in normal and ovariectomised rats.

\section{Comments}

In addition to the discovery that statins can stimulate bone formation, there is also in vitro evidence that statins can inhibit bone resorption. Intriguingly, some bisphosphonate drugs also inhibit bone resorption by inhibiting the mevalonate pathway in osteoclasts. Unfortunately however, the statins currently available are unsuitable as bone anabolic agents in humans, owing to their selective targeting to liver rather than bone. Also, the equivalent dose in humans to that found to be anabolic in rats is much 
higher than the standard dose for cholesterol-lowering and would risk serious side effects. However, these observations highlight the importance of the cholesterol biosynthetic pathway in bone metabolism and indicate a possible new therapeutic approach for stimulating bone formation.

\section{Methods}

A reporter construct consisting of the BMP-2 promoter linked to the firefly luciferase gene was transfected into an osteoblast cell line, and used to screen a library of over 30,000 natural compounds to identify agents that could stimulate BMP-2 expression.

\section{References}

1. Mundy G, Garrett R, Harris S, Chan J, Chen D, Rossini G, Boyce B, Zhao M, Gutierrez G:

Stimulation of bone formation in vitroand in rodents by statins. Science. 2000, 286: 1946-1949.

This PDF file was created after publication. 